\title{
Recent developments in the design of fast ships
}

\author{
Desarrollos recientes en el diseño de embarcaciones rápidas
}

\begin{abstract}
During the last twenty years, Damen Shipyards, a multinational shipbuilding group with 6000 employees worldwide, has done extensive research on the development of hull designs for fast monohull vessels. In the 1990s the Enlarged Ship Concept was developed, leading to highly improved sea keeping capabilities and vessel behaviour in waves at high speed. This hull design concept was applied in the Damen SPa 4207 patrol vessel and has proven extremely successful, reducing vertical accelerations by $50 \%$ and, thus, allowing vessels to keep operating at high speed in waves. Over 25 units of the Damen SPa 4207 have been delivered so far. After the successful introduction of the Enlarged Ship Concept, Damen and Delft University continued developing the next generation hull form: the axebow design. Compared to the already good sea keeping capacities of the Enlarged Ship Concept, model tests indicated a further reduction of vertical accelerations. This was proven by real-time measurements on the first built axebow vessels in 2006 and 2007. In the last 3 years, over 30 axe bow supply vessels have been delivered to very satisfied operators. As a next step, Damen has applied the axe bow design to the latest patrol vessel design, the Damen SPa 5009. The first vessel of this design is currently under construction and its trials are scheduled by the end of 2011. The paper describes the background of the research done by Damen and Delft University, focusing on the mathematical and scientific aspects of the axebow design and its application on various ship types. The development and design of the latest Damen patrol vessel, SPa 5009, will be introduced, describing its seakeeping performance, operatability and crew ergonomics. Finally, the paper will mention the current and future research topics that Damen and Delft University are working on together, identifying the developments of the future generation patrol vessels.
\end{abstract}

J. A. Keuning ${ }^{2}$

Key words: High-speed craft, Fast patrol vessels, Hull form design, Axe bow design, Seakeeping behaviour.

\section{Resumen}

Durante los últimos 20 años, los astilleros Damen, un grupo multinacional constructor de buques con 6000 empleados alrededor del mundo, han investigado ampliamente sobre el desarrollo de los diseńos de cascos para embarcaciones rápidas monocasco. Durante los 90, el Concepto del Buque Ampliado fue desarrollado, conllevando a capacidades mejoradas de navegabilidad y comportamiento de la embarcación en oleaje a alta velocidad. Este concepto de diseño de casco se aplicó en la embarcación de patrullaje Damen SPa 4207, y se ha comprobado extremadamente exitoso, reduciendo aceleraciones verticales por $50 \%$ y, así, permitiendo que las embarcaciones sigan operando a alta velocidad en oleaje. Más de 25 unidades del Damen SPa 4207 se han entregado hasta la fecha. Luego de la presentación exitosa del Concepto del Buque Ampliado, Damen y la Universidad Delft continuaron desarrollando la forma de casco de la siguiente generación: el diseño de proa en arco (axebow design). Comparado con las ya buenas capacidades de navegabilidad del Concepto del Buque Ampliado, pruebas del modelo indican adicional reducción de la aceleración vertical. Esto se comprobó mediante mediciones en tiempo real en las primeras embarcaciones construidas con proa en arco (axebow) en 2006 y 2007. En los últimos tres ańos, más de 30 buques de suministro de proa en arco se han entregado a operadores muy satisfechos. Como paso siguiente, Damen ha aplicado el diseño de proa en arco a su más reciente diseño de embarcación de patrullaje, el Damen SPa 5009. La primera embarcación de este diseño está actualmente bajo construcción y sus pruebas están programadas para fines de 2011. El documento describe los antecedentes de la investigación realizada por Damen y la Universidad Delft, enfocándose en los aspectos matemáticos y científicos del diseño de proa en arco y su aplicación en varios tipos de embarcaciones. El desarrollo y diseño de la más reciente embarcación de patrullaje, SPa 5009, se presentará, describiendo su desempeño de navegabilidad, operabilidad y ergonomía de tripulación. Finalmente, el documento mencionará los temas de investigación actuales y a future sobre los cuales Damen y la Universidad Delft están trabajando conjuntamente, identificando los desarrollos de las embarcaciones de patrullaje de futura generación.

Palabras claves: embarcaciones de alta velocidad, Embarcaciones rápidas de patrulla, diseño de la forma del casco, diseño de proa en arco, Comportamiento de navegabilidad.

Date Received: Novembre 6th, 2010 - Fecha de recepción: 6 de Noviembre de 2010

Date Accepted: December 30th, 2010 - Fecha de aceptación: 30 de Diciembre de 2010

${ }^{1}$ Damen Shipyards - High Speed Craft Department. e-mail: jlg@damen.nl; eh@damen.nl

${ }^{2}$ TU Delft, Delft University of Technology - Shiphydromechanics Department. e-mail: J.A.Keuning@tudelft.nl 


\section{Introduction}

The combination of high forward speeds and waves of any significance has since considerable time been a serious challenge for designers and operators of fast ships. The possibility of a fast ship to maintain its intended high forward speed under those conditions is a serious measure for its operability. For decennia, Damen Shipyards has put considerable effort into improving the operability of fast ships in a seaway. During the last two decades, this has resulted in close cooperation with the Ship hydromechanics Department at Delft University of Technology. As a result of this cooperation, some successful new concepts have been developed and brought to the market.

In the present paper an oversight of these developments will be presented and some results obtained with these new concepts when compared with existing contemporary designs will be highlighted.

\section{Problem Definition}

From full-scale experience, it is known for a long time that severe motions and, in particular, high vertical accelerations are the main reason for speed reduction of fast ships in a seaway. This speed reduction occurs primarily in head and bow quartering waves. Due to the large motions and the sometimes very high peaks in the vertical accelerations during impacts most crews apply voluntary speed reduction to maintain workable conditions on board of their ships to prevent possible structural damage to the ship and to guarantee the safety of the crew and the ship.

Principal reasons for these phenomena to occur in particular with fast ships originate from the fact that, both for practical and economical reasons, most fast ships are generally small, say smaller than 50 meters in overall length and, therefore, the waves they are sailing in are relatively large. Also, due to the high forward speeds in head waves the frequency of encounter is high, which has a very negative effect on the acceleration levels aboard these ships.
For a long time, the emphasis in the design of fast ships has been put on the minimal obtainable resistance at the required maximum speed. This had to be obtained under calm conditions. Operation of the ships in a seaway was for a long time not considered as an important design issue. In some design areas, such as the fast-ferry markets, the search for improved seakeeping behaviour was found in the design and application of ever larger vessels. By doing so, the mentioned deviancies in the behaviour in waves could be partly overcome, but this is not a solution applicable in most of the other areas of application of fast ships. The focus on calm water performance has lead to particular trends in the fast ship designs, such as low deadrise, low length to beam ratios, and relatively short and heavy hulls, i.e., low length - displacement ratios. These trends, however, showed unfavourable for the behaviour of these fast ships in a seaway. Thereby, when these ships moved their operational areas from the more sheltered inland waters to the more exposed sea areas a new design philosophy had to be developed.

\section{The development of new design concepts}

An important role in this new development, at least within the Damen and DUT cooperation, was played by the results obtained from a considerable amount of full-scale measurements carried on board various fast Patrol Boats and Search and Rescue (SAR) vessels of different sizes on the North Sea. As reported by Keuning in Ref [1] it became obvious that improving the operability in head waves meant reducing the peaks in the vertical accelerations on board as much as possible. The significant (or "average") value of the vertical accelerations did not prove to be the prime factor for the crews to voluntarily reduce the speed of the ship, but the occurrence of the more scarcely high vertical peaks or slams. Avoiding these high peaks, therefore, became a primary driving factor in the designs. To demonstrate this, Fig. 1 is introduced with the distribution of the peaks in the irregular time signal of the vertical accelerations of a fast ship. 
The horizontal scale represents the change of occurrence and is "transformed" according to the Rayleigh distribution, the vertical scale presents the magnitude of the vertical accelerations in meters per second squared.

Fig. 1. Distribution of peaks and troughs of an acceleration signal

Vertical acceleration levels

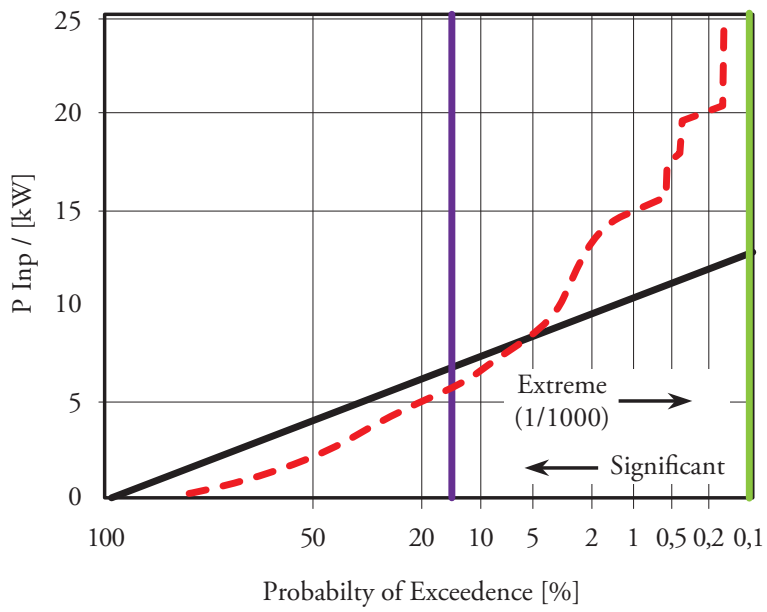

The wish to avoid the high peaks in the acceleration signal for improved operability in a seaway means that a distribution according to the black (straight) line is very much to be preferred above the distribution following the red line. This holds true even though the significant value corresponding with the black distribution line is higher than that of the red line.

These insights led to the development and introduction of the Enlarged Ship Concept (ESC) in 1995 [1], [2]. First by the so called "simple ESC 4100 " in which only the length was increased without changing the section and bow shape of the design and which proved already a considerable improvement over the conventional designs. This concept was subsequently followed by the development of the more improved concept called "TUD 4100" in which improved bow geometry was introduced. These were followed by the more radical new design concept called the "AXE 4100" by applying the philosophy in full of the AXE Bow Concept (ABC) in 2001 [3], [4]. Based on an extensive research project FAST 1 carried out in 2003 by the Ship Hydromechanics Department at
Delft University of Technology jointly sponsored by Damen, Royal Netherlands Navy, US Coast Guard and MARIN, all relevant aspects of the behaviour of the $A B C$ in waves from any direction were analyzed and evaluated. This showed such promising results that Damen decided to introduce the $\mathrm{ABC}$ designs on the market in 2006 and these designs have been quite successful.

The philosophy behind these concepts is that, first of all, the length should be brought back into design. By increasing the length without changing the beam, the forward speed and the functionality of the design, the L/B ratio becomes larger, the L/ DISP ratio also becomes larger and there is a more suitable place available to position the important areas on board such as the wheelhouse or passenger areas can be found, i.e., the ESC 4100.

By increasing the length without changing the functionality, more space (void space) also becomes available - enabling the design of the hull shape more from an optimal hydromechanics point of view.

To avoid severe impacts during sailing in waves, the hydrodynamic lift generated at the fore sections of the hull has to be reduced. Also, the dominant wave exciting forces for fast ships has been proven to be the so-called non-linear Froude Kriloff forces. These have to be reduced as far as possible, which is achieved by introducing changes in submerged volume below and above the waterline both in the horizontal and the vertical direction. This results, in particular at the bow, in taking care that only small changes in submerged geometry at the forward sections of the hull do occur when these sections are moving in and out of the water due to provoked motions in the incoming waves. This leads to very sharp bows with non-flared sections and very deep forefoots with possibly a negative contour. The sheer line is significantly raised to generate more freeboard forward and so increase the reserve buoyancy. To illustrate this, the lines of a Conventional, an ESC, and an ABC design are depicted in Figure 2. A more detailed description of these design concepts was presented by Gelling at the 2007 IPIN Conference [5]. 
Fig. 2. The line plans of the simple ESC, the improved ESC (TUD 4100), and the ABC designs

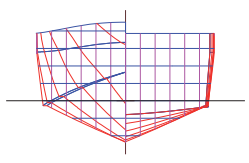

ESC 4100
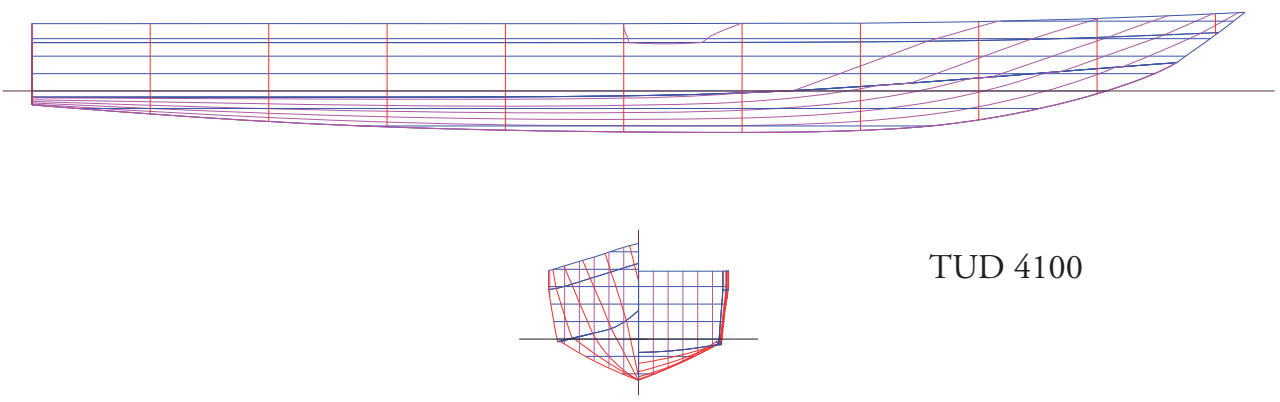

TUD 4100
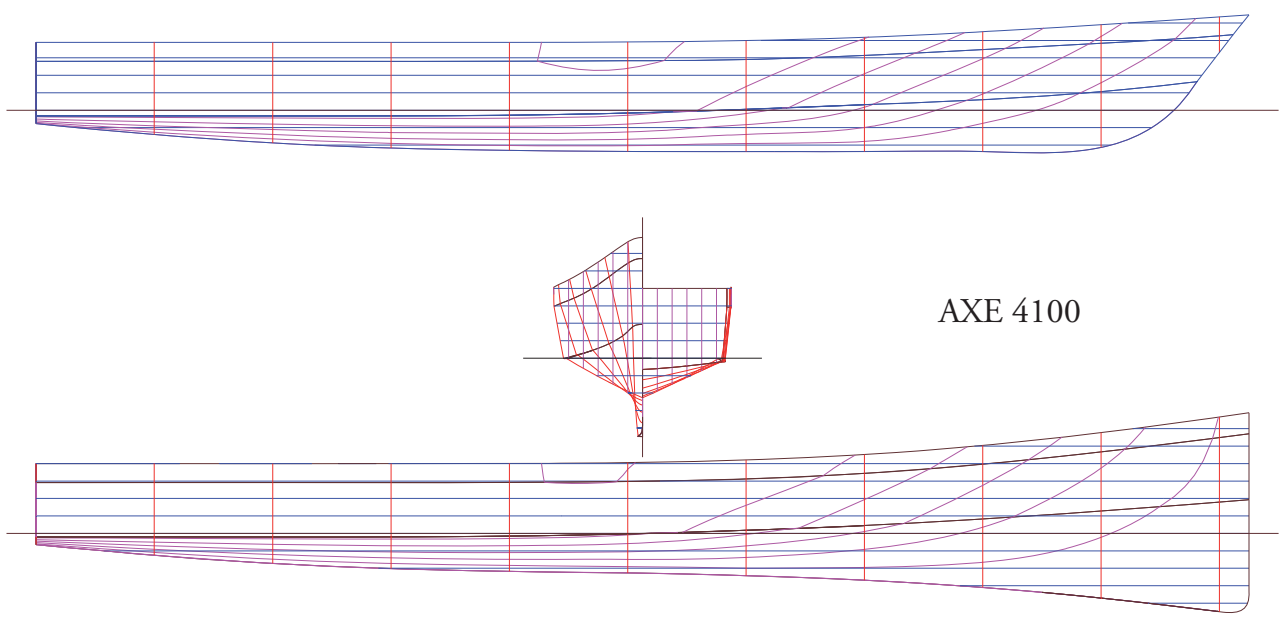

The improvements obtained with these designs in the vertical accelerations are clearly demonstrated by the results from a comparative study presented in Fig. 3. Here, the peak distributions in the vertical accelerations at the bow of the three concepts sailing at high speeds in head waves corresponding to a Seastate 5 on the North Sea are plotted on the basis of a Rayleigh distribution scale. From these plots, it is obvious that the application of the ESC and the ABC design philosophy leads to a significant reduction of the high peaks with limited occurrence, i.e., the right hand side of the figure is much lower. In particular, the AXE 4100 is superior in this respect. This leads to a large improvement in the operability of these craft. These theoretical results are in the meantime fully confirmed by full-scale experience with the actual ships.

On the market both concepts are very successful.
This is amongst other things demonstrated by the fact that from the ESC design more than 75 vessels have been sold since 1997 and from the ABC design more than 30 since its introduction in 2007.

Fig. 3. The comparison of the distributions of the vertical accelerations at the bow for the new design concepts

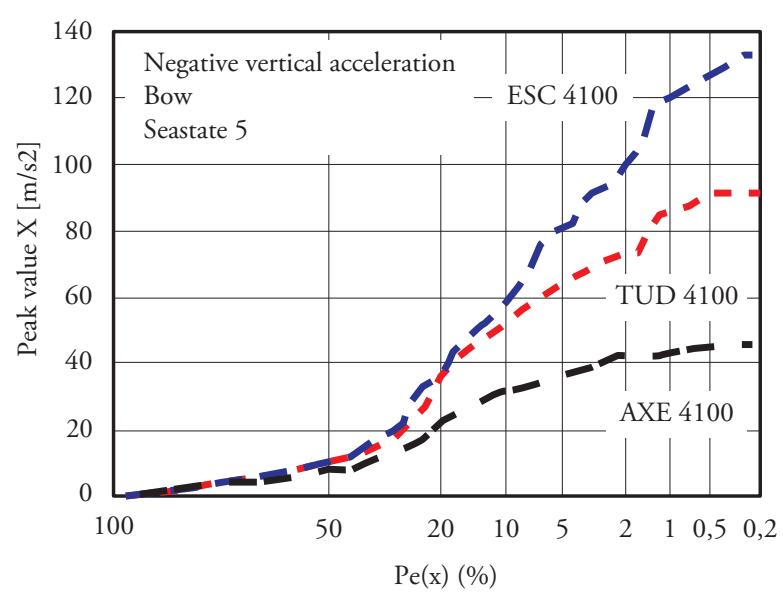


The ESC has been built primarily in the function of Patrol Boat in the range from 40 till 60 meters overall length with speeds ranging from 22 to 30 knots. The Axe bow designs range from 30 till 60 meters overall length and are primarily used as Fast Crew Suppliers, Fast Yacht Support Ships, and more recently Patrol Boats. Some typical examples are depicted in Fig. 4.

Fig. 4a. The AXE Bow Concept applied as Fast Yacht Support vessel of $50 \mathrm{~m}$ lengthconcepts

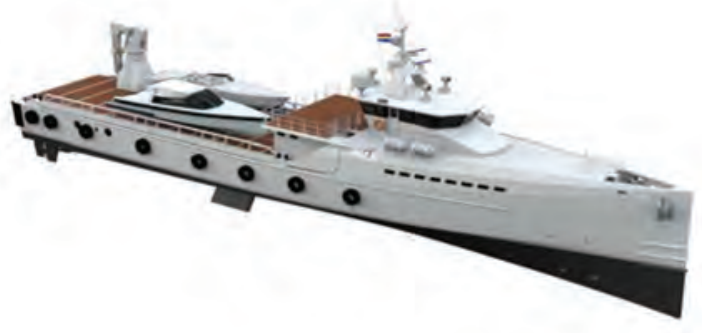

in catamarans. An important aspect was if and if so, which modifications had to be introduced for application of the concept with catamarans.

During the last decade, a considerable demand has come from the market for relatively small catamarans with improved seakeeping
One of the particular beneficial aspects of the application of the AXE Bow turned out to be the circa $20 \%$ lower fuel consumption in waves compared with conventional ships due to the considerable lower added resistance because of the waves. These good results obtained with the designs with the AXE Bow led to a new research project in 2009 into the possible application of this concept

Fig. 4b. The ESC as $42 \mathrm{~m}$ Patrol Boat

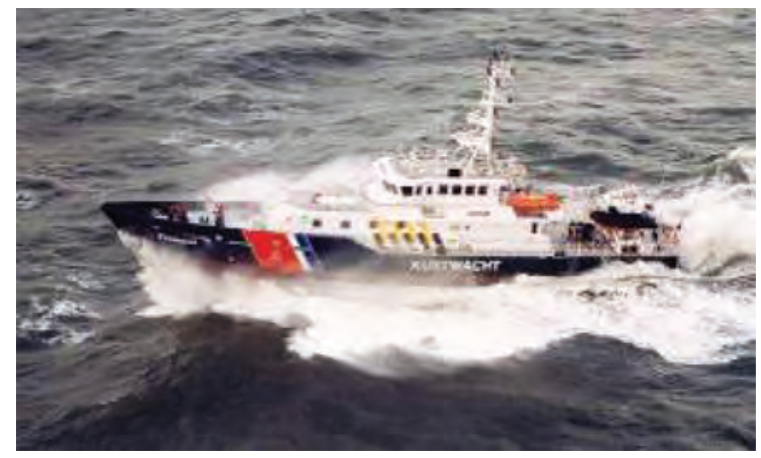

performance. These have to be operated from low to moderate sea states in particular for application as service vessels for the offshore wind mill farms at the North Sea. Typical length of these vessels is in the 20-meter range and typical speeds are up to 25 knots in calm water. In addition to the usual requirements for low levels of vertical accelerations

Fig. 5. The lines plan of the TwinAxe Catamaran concept
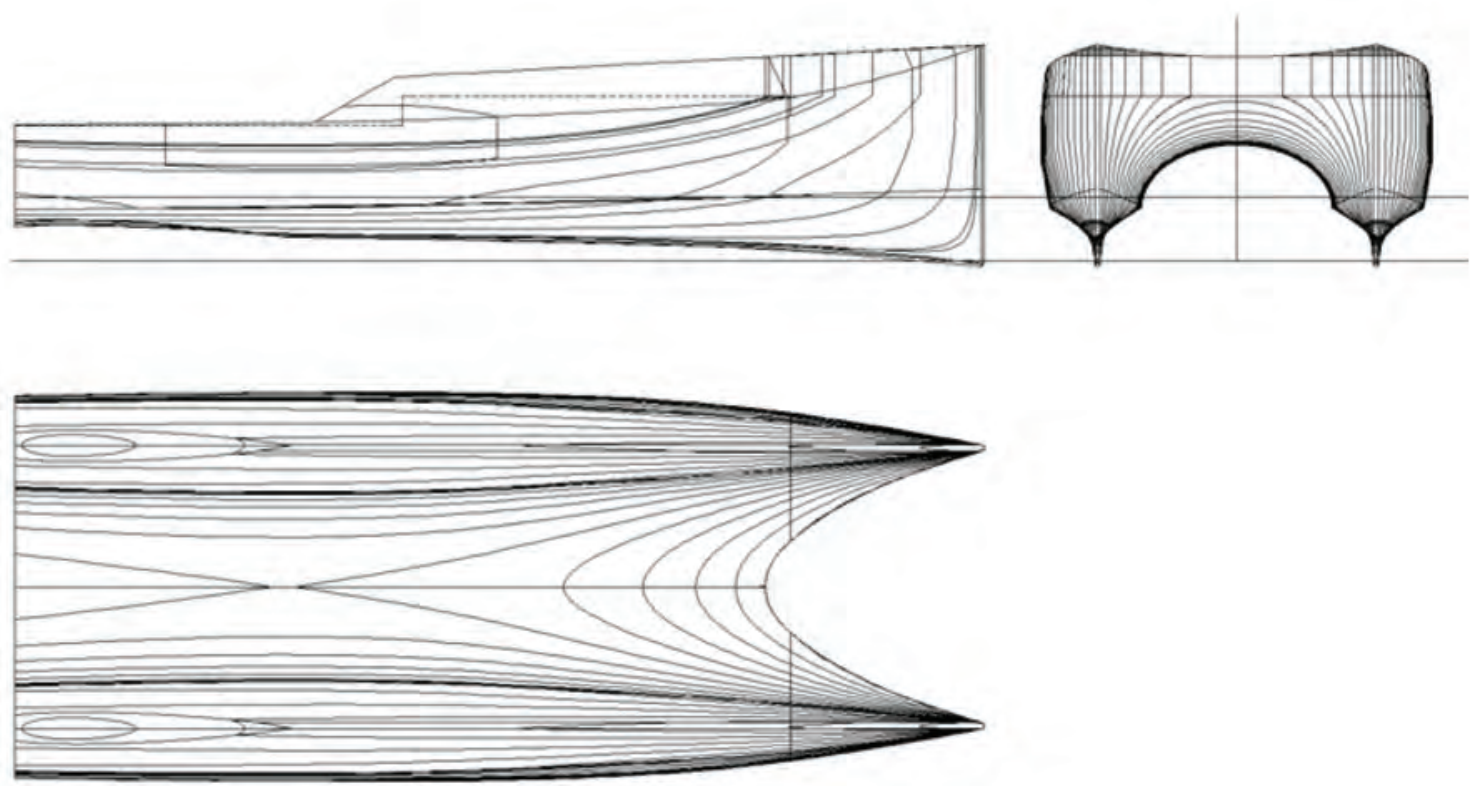
and small motions, the improvement in the seakeeping behaviour of the catamaran has also to be found in the avoidance of wet deck slamming. This put special focus on the design of the hull shape.

The solution for the optimized catamaran hull design was found in applying the Enlarged Ship Concept first and so to extend the overall length from 20 to 25 meters. Then the AXE Bow concept was applied on both hulls. To avoid wet deck slamming the vertical motion of the fore ship had to be introduced so that when sailing into the wave the deck was lifted but without violent accelerations. Thereby, a special geometry was designed between the hulls to gently introduce the wave forces, but not to eliminate them completely. Finally, the avoidance of the wet deck slamming was found in cutting away the foremost part of the wet deck about $20 \%$ of the overall length. This was also made possible by the application of the enlarged ship concept.

The research project aimed at comparing between the TwinAxe concept and a comparable conventional catamaran. It was decided that the comparison between the two designs would focus on the resistance in calm water and the heave and pitch motions and vertical accelerations in head waves. In addition, the possible tendency for bow diving in following seas was also investigated for both designs.

The calm water resistance of the two designs is compared in Fig. 6. From these results, it is obvious that the resistance of the TwinAxe is lower than that of the conventional catamaran. This is in particular due to the higher $\mathrm{L} / \mathrm{B}$ ratio of the hulls and their bigger separation. A typical crossover is found at 25 knots.

From the results in waves only the vertical accelerations at a location $10 \%$ of the Loa aft from the bow are shown. The tests have been carried out in a typical North Sea Seastate and at a forward speed of 25 knots. These results are depicted in Figs. 7.
Fig. 6. Calm water resistance of the TwinAxe and the Conventional Catamaran

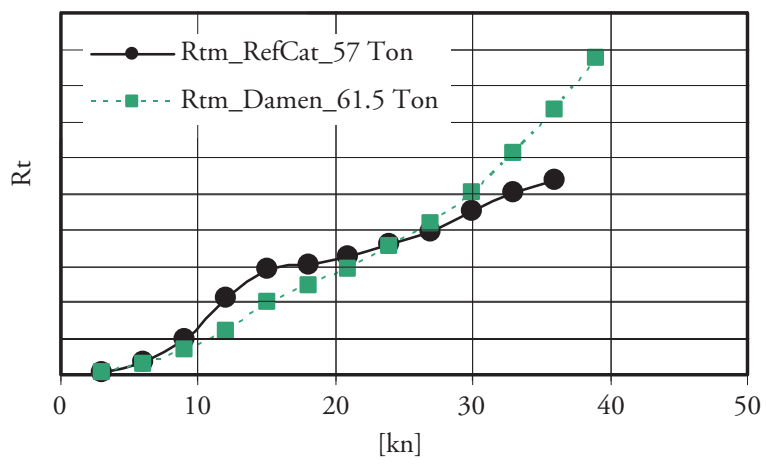

Fig. 7a. The distribution of the vertical accelerations at the bow for the TwinAxe Catamaran at 25 knots in irregular waves with significant wave height $\mathrm{Hs}$ of $1.5 \mathrm{~m}$.

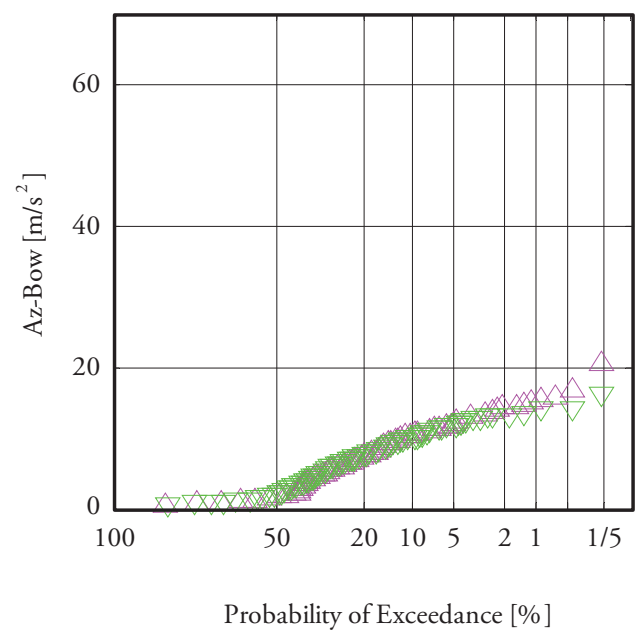

Fig. 7b. The distribution of the vertical accelerations at the bow for the Conventional Catamaran at 25 knots in irregular waves with significant wave height $\mathrm{Hs}$ of $1.5 \mathrm{~m}$.

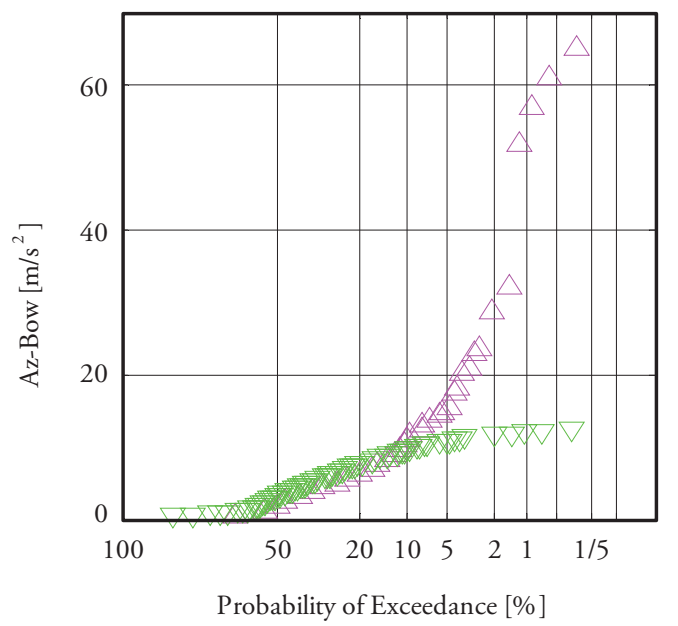


The enormous gains achieved in the vertical acceleration levels obtained with the application of the TwinAxe concept are rather obvious.

It is also well worth mentioning that under all the conditions tested, i.e., with significant wave heights ranging from 1.0 to 2.5 meters and forward speed of 25 knots no wet deck slamming occurred with the TwinAxe. In the following sea conditions no bow diving occurred also. Although the development time of this new catamaran concept was rather short, the results obtained were so promising that already a couple of these catamaran designs have been sold. A typical rendering of one of these designs is depicted in the next Fig. 8.

Fig. 8. Rendering of the TwinAxe Catamaran as windmill support ship

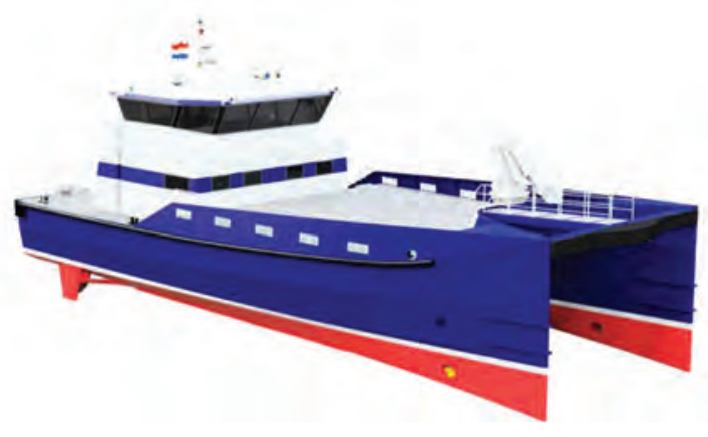

Another application of the new concepts was found in the design of a possible new Search and Rescue (SAR) vessel for the Royal Dutch Lifeboat Institute (KNRM). At present, they are looking for a possible replacement of their existing fleet of 18.5-meter long RIB vessels capable of a forward speed of maximum 35 knots and to be used on the North Sea under all weather conditions. Given the special functionality of these SAR boats and their possible use under very extreme environmental conditions, some modifications to the original AXE Bow design had to be made. The new SAR boats should have improved seakeeping performance when compared to the present ones when head and bow quartering seas are concerned. Under all other conditions, they should at least have similar performance and preferably better. Particular attention had to be paid to the possible occurrence of broaching in stern quartering seas. Also the tendency to bow diving in extreme following waves should be considered.

Finally, the manoeuvrability of these SAR ships in severe waves, both head and following, should be an issue. The boats should also be self righting. Based on these requirements, a new design has been developed. Particular points in the design were the enlargement of the hull, the application of the AXE bow but without the typical negative sloped contour (downwards) forwards because these SAR boats should be able to take the ground frequently and violently. For safety and manoeuvrability, reasons the boats are equipped with water jets of ample power. The tube along the entire length of the hull is there mainly for fendering reasons. The most striking difference with the existing boats is the very fine bow with increase sheer and freeboard. Compared with the existing boats, the deadrise and the hull $\mathrm{L} / \mathrm{B}$ ratio are increased. A rendering of this design is depicted in Fig. 9.

Fig. 9. Proposal for a new SAR vessel for the KNRM with Loa $=21 \mathrm{~m}$ and $\mathrm{Vs}=35$ knots

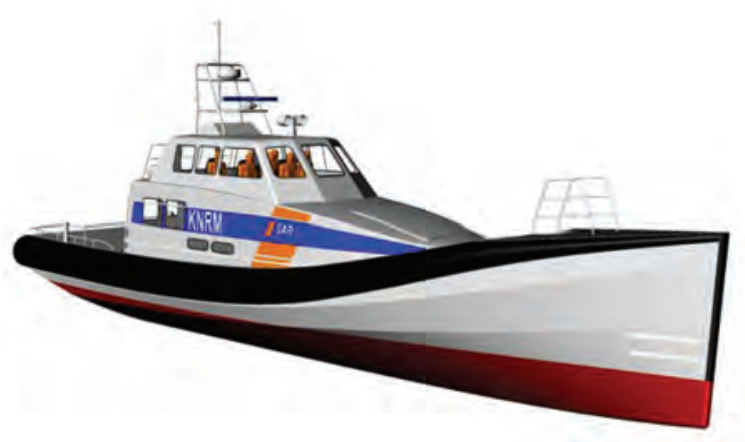

From an extensive series of experiments carried out with a model of this new design and a model of the existing boat in the towing tank, it has been demonstrated that a considerable improvement in the head seas conditions has been achieved with the new concept, without any loss of performance under following and stern quartering conditions.

\section{Development of new active controls}

In addition to these new concept developments, research has also been carried out in the area of 
active control for fast ships. This originates from the effect that both the size and the high forward speed of these craft make the use of actively controlled fins very attractive. Two typical examples with promising results will be mentioned here:

- an actively controlled trim flap or interceptor at the transom of the boat to control pitch, heave, and vertical accelerations and

- a retractable vertical bow rotor below the bow of a fast ship to improve directional control and reduce the roll and yaw motion in stern quartering and following waves.

The idea of controlling ship motions with an active control on the trim flaps at the transom is not new. In 1984 Wang [7], amongst others, published experimental and computational results of a hard chine planing hull equipped with actively controlled trim flaps. In his research, he already showed that considerable gains could be obtained with this control. Recently, Rijkens extended this research with model experiments to determine the forces and moments delivered by both active flaps and active interceptors at the transom. The results of these systematic series of experiments have been used to extend the calculation procedure used in the mathematical model for the motions of fast ships in waves. The type of flaps and interceptors investigated by Rijkens are depicted in Fig. 10.

Fig. 10. Type of flaps and interceptors investigated by Rijkens

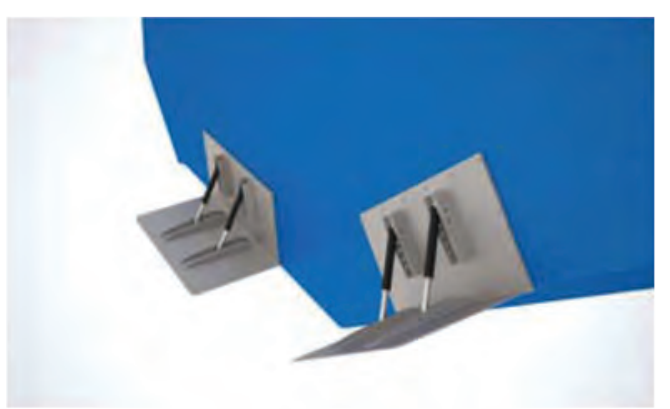

And the results he obtained with the flaps on the vertical accelerations at the bow are depicted in

Fig. 11a. Vertical acceleration at the bow without flaps

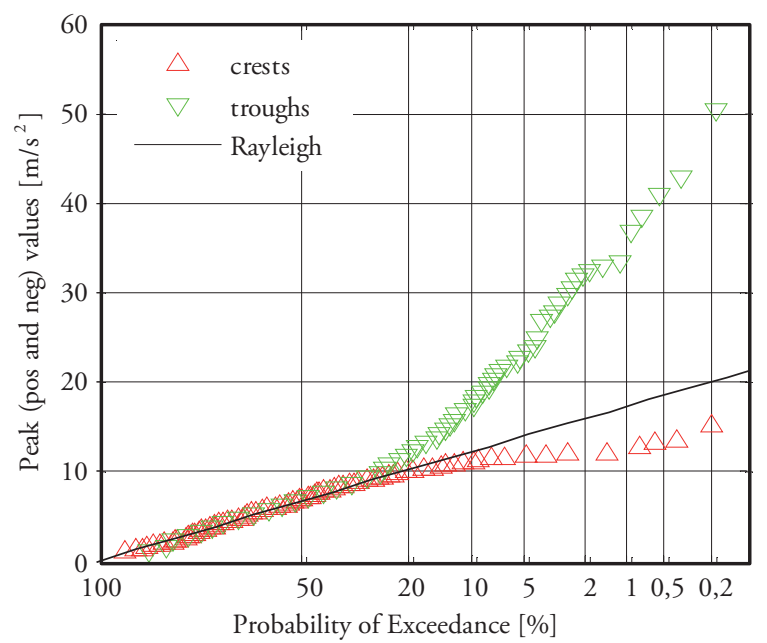

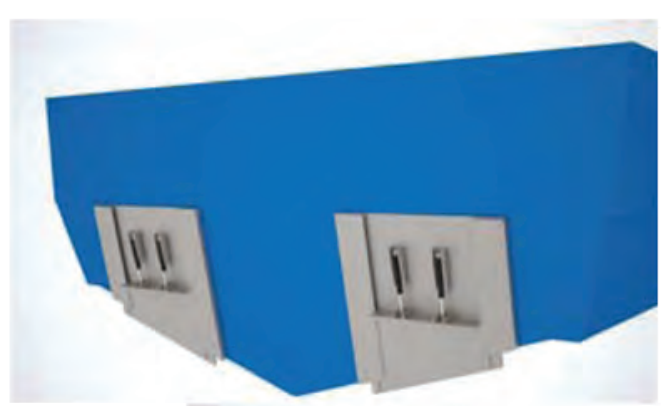

Figs. 11, for the tests with and without flaps.

Fig. 11b. Vertical acceleration at the bow with active flaps

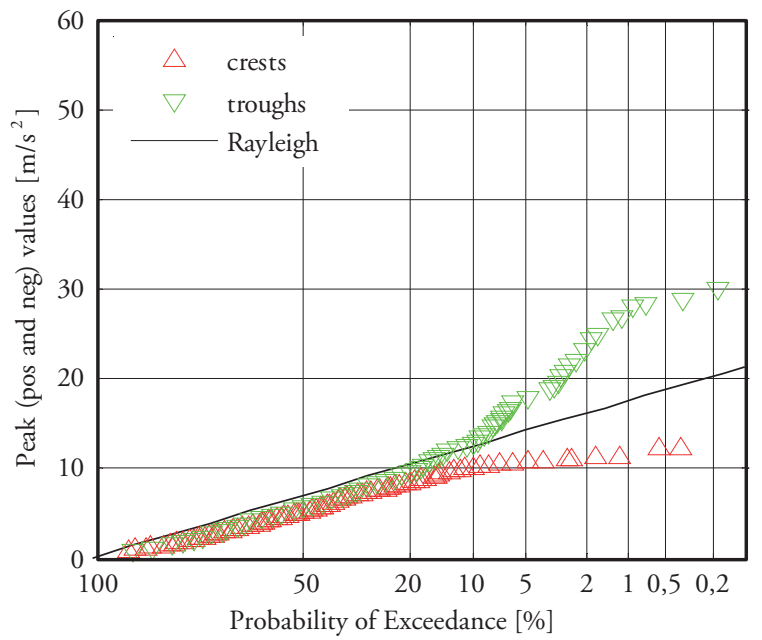


Finally, a new device has been developed for controlling the roll and yaw motions of fast ships in stern quartering waves.

It is known from full-scale experience and model experiments that quite a few fast ship concepts are sensitive for severe combined roll and yaw motions in stern quartering waves, sometimes leading to complete loss of control and a broach. This is aggravated once again by the fact that most fast ships are relatively small compared to the surrounding waves.

The phenomenon of the broach will not be fully explained here but an extended description can be found in Ref [8]. The Vertical Bow Rotor (VBR) device is a vertical and retractable Magnus Rotor underneath the bow of a ship, preferably an AXE Bow because the very geometry of such a bow easily enables the housing of such a device. An additional benefit of the AXE Bow and VBR combination is that the VBR cylinder is and will remain deeply submerged when the ship is heaving, rolling, and pitching in large waves. A Magnus Rotor has the property of efficiently generating a very high lift force when the cylinder is put into rotation. The combination of the forward velocity of the ship and the rotation of the cylinder produces a lift force perpendicular to the forward velocity of the ship. By changing the rotations per minute (RPM) of the rotor and/or the direction of rotation, the lift force can be fully controlled both in magnitude and direction; almost like a rudder, but more efficiently. The VBR in this application is made retractable because under those situations or conditions in which its application is not necessary it can be easily retracted and so the effect of the rotor on the ship resistance remains. A typical configuration of such a rotor is depicted in Fig. 12.

Fig. 12 .
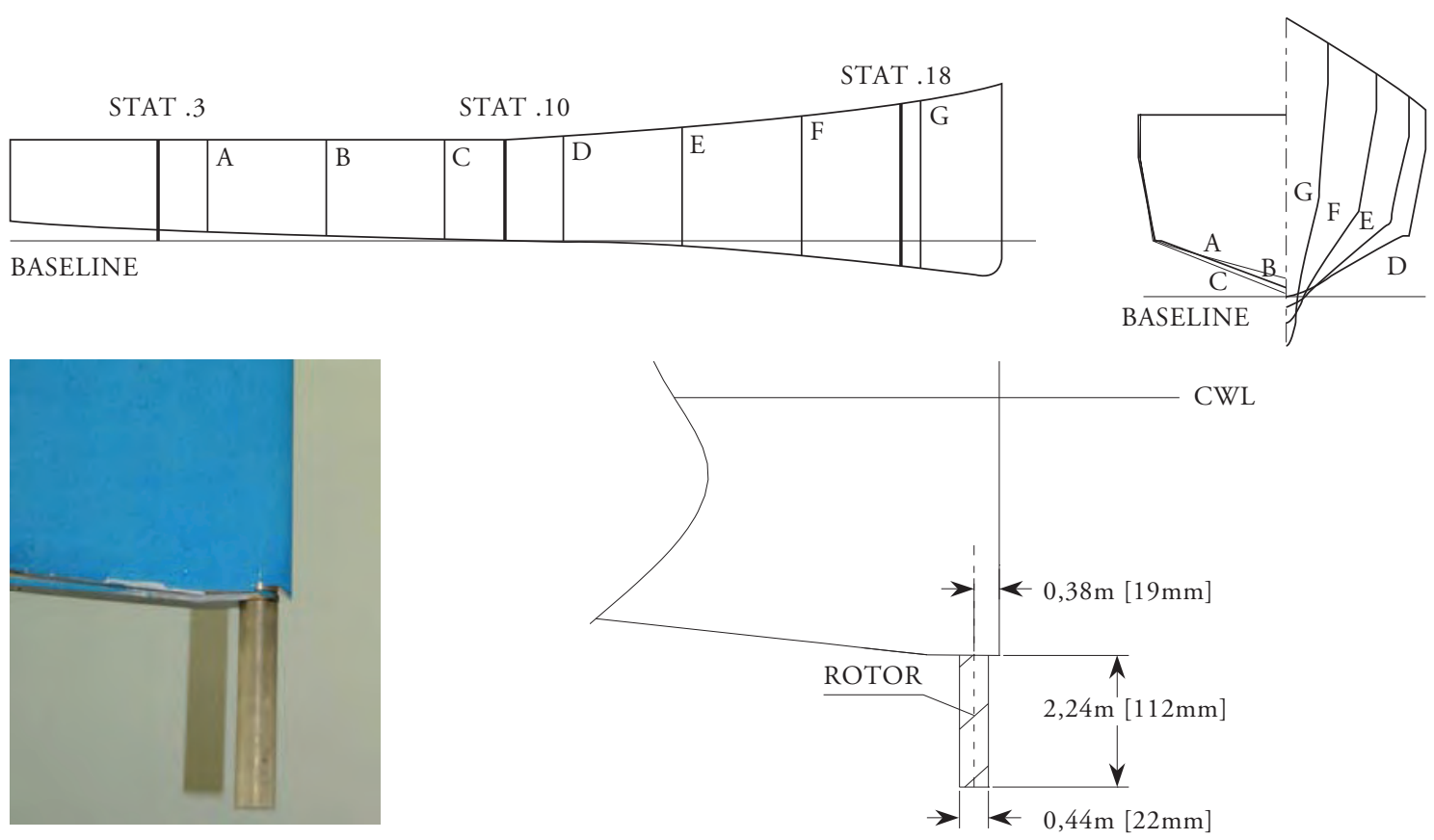

To investigate the effect of the VBR on the dynamic behaviour of a fast patrol boat in stern quartering waves, extensive experiments have been carried out in the MARIN Ship Motion Basin in Wageningen. The ship tested was a 35-meter Length over all (Loa) Fast Patrol Boat from DAMEN and the
VBR was dimensioned based on an extensive systematic test with various rotors in the towing tank of the Delft University of Technology. A few of the results are presented here. They show the effect of the VBR on the roll and the yaw motion in an irregular sea with a significant wave height of 
2.5 meters and a peak period, Tp, of 7.6 seconds, a typical North Sea spectrum energy distribution over the frequency range. The waves approached from 315 degrees (stern quartering) and the ship travelled at a forward speed of 22 knots. From earlier tests, it was found that this was the worst combination of waves, heading, and forward speed. The distribution plots show the crests and troughs of the roll and yaw motions with and without the VBR.

Fig. 13. Distribution of roll and yaw motions in stern quartering seas with $\mathrm{Hs}=2.5$ meter at 22 knots with and without VBR
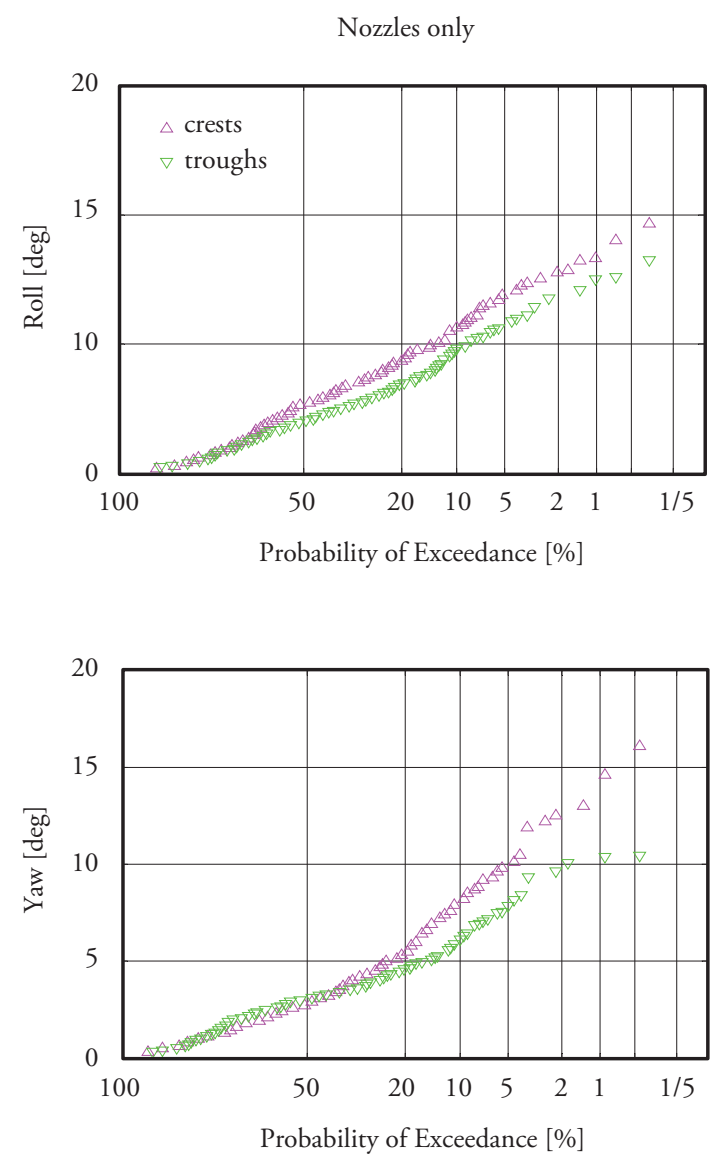

These results show that a reduction of almost $40 \%$ on average in the roll motion and of almost $60 \%$ in the yaw motion can be achieved under those conditions. To investigate the extended application of the VBR, measurements have also been carried out in Seastate with 3.5-meter significant wave height, conditions under which the ship without the active VBR now and then broached. These results are presented in different manner in the following figures, i.e., in Fig. 14 as Significant Double Amplitudes (SDA) of the motions and as Maximum Plus and Minus amplitudes in Fig. 15. From these results, it can be concluded that the
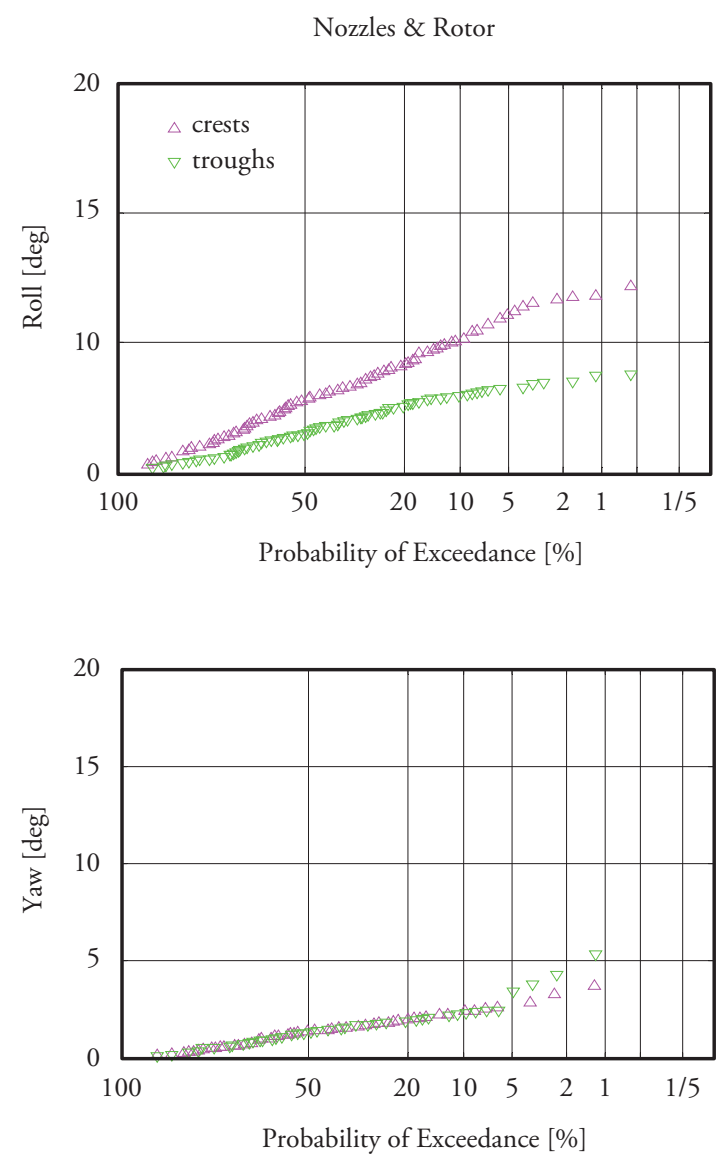

introduction of the VBR has very positive effects on the controllability and the reduction of the roll and yaw motions in stern quartering seas. The operability of fast vessels under those conditions can be very much improved by applying VBR. Under the conditions tested, the vessel used for the experiments did not experience any broaching behaviour with the VBR activated whilst without the VBR some broaches did occur. Although not specifically investigated yet, it appears that using the VBR is especially suited in combination with the AXE Bow. 
Fig. 14. Significant Double Amplitude for Roll and Yaw with and without the Bow Rotor at 22 knots in a seaway

from a angle of incidence of 315 degrees and with a significant wave height of 3.5 meters

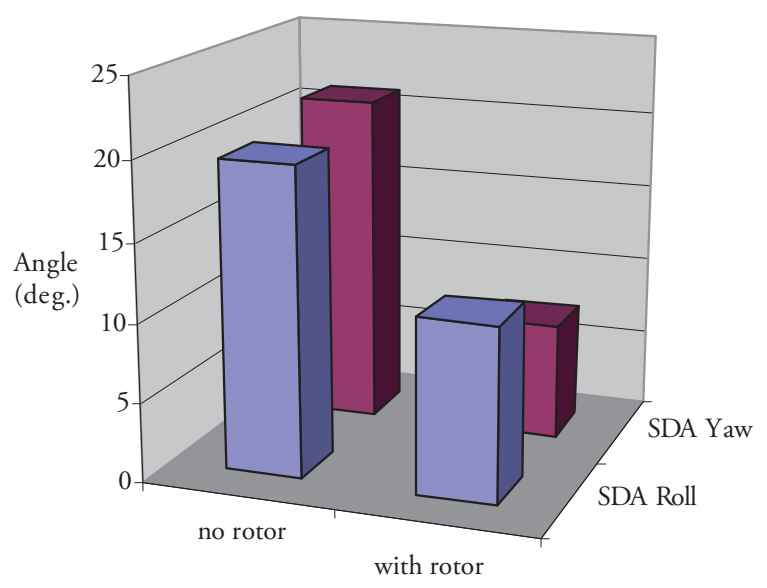

Fig. 15. Maximum Roll and Yaw angles with and without the Bow Rotor at 22 knots in a seaway from an angle of incidence of 315 degrees with a significant wave height of 3.5 meters

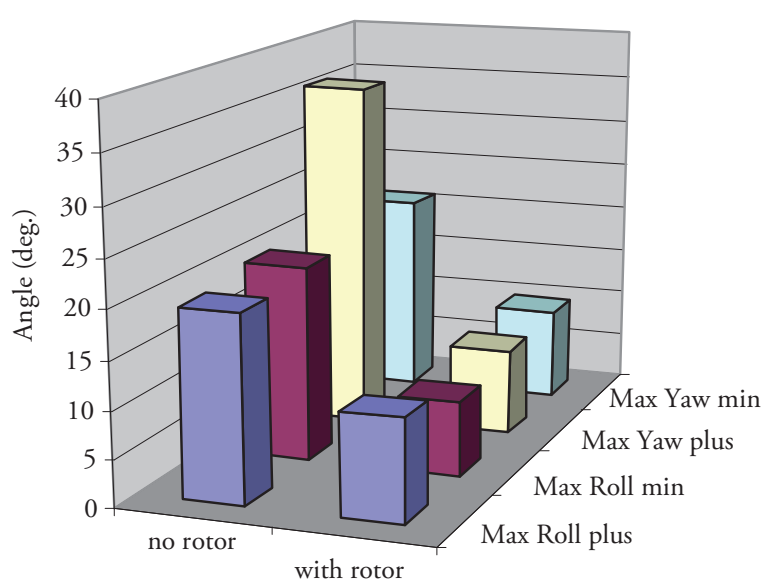

\section{Conclusions}

The High-Speed Craft area lends itself very much for improvements in design. In particular, in improving the operability - in general - of fast ships in a seaway is a very interesting field of research and development. Some noticeable results have been achieved in this area over the last decades through intensive cooperation among universities and research institutes with the industry. It is to be expected that if this cooperation is continued and intensified, in the years to come new and very fruitful results will again be achieved.

\section{References}

[1] BOSCH, J.J. VAN DEN "Tests with two planing boats in waves" TU Delft Laboratorium voor Scheepsbouwkunde, Report 238, June 1969.

[2] BLOK, J.J. AND ROELOFFS, H.W. 'The influence of the Forebody Deadrise on the performance in a Seaway" MARIN Report No 49207-1-HT April 1989.

[3] KEUNING, J.A. "Nonlinear Heave and Pitch Motions of Fast Ships in Irregular Head Waves" ASNE High Speed Marine Vehicles Conference, Washington, June 1992.

[4] KEUNING, J.A. "The Non Linear Behavior of Fast Monohulls in Head Waves" PhD Thesis, Delft University of Technology, September 1994.

[5] GELLING, J.L. AND KEUNING, J.A. "Developments in hullshapes for high speed craft" IPIN Conference 2007, Cartagena, Colombia.

[6] KEUNING, J.A. AND PINKSTER, J. "Further Design and Seakeeping Investigations into the Enlarged Ship Concept" FAST Conference Proceedings 1997, Sydney Australia.

[7] KEUNING, J.A., PINKSTER, J. AND WALREE, F. VAN "Further Investigation into the Hydrodynamic Performance of the AXE Bow Concept" Proceedings of the WEGEMT Conference on High Performance Marine Vehicles September 2002 Ischia, Italy.

[8] KEUNING, J.A., TOXOPEUS, S. AND PINKSTER, J. "The Effect of Bow Shape on the Seakeeping Performance of a Fast 
Monohull” FAST Conference Proceedings Southampton, September 2001.

[9] OOMS, JAND KEUNING, J.A. "Comparitive Full Scale Trials of Two Fast Rescue Vessels" International Conference SURV 4, 13\&14 may 1997 Gothenburg.
[10] KEUNING, J A AND VISCH, G. The Application of a Vertical Bow Rotor on an AXE Bow FAST Conference Athens, Greece 2009. 